\title{
Characterization of the mineralization of the Groundwater in high Basin of Guir (Morocco) by geochemical and geostatistical
}

\author{
Nouayti Nordine ${ }^{1}$, Nouayti Abderrahime ${ }^{2}$, Khattach Driss $^{2}$, Hilali Mohamed ${ }^{3}$, and El khadraniNajib ${ }^{4}$ \\ ${ }^{1}$ Laboratory of Water and Environmental Engineering, Al Hoceima National School of Applied Sciences PO Box 03, Ajdir Al \\ Hoceima. \\ ${ }^{2}$ Laboratory of Applied Geosciences, Faculty of Sciences, University Mohamed First Oujda 60000, Morocco \\ ${ }^{3}$ Research Team of Mining, Water and Environment Engineering, Faculty ofSciences and Techniques, Moulay Ismaïl \\ University,52000,Post Box: 509, Boutalamine,Errachidia, Morocco. \\ ${ }^{4}$ Research Unit on Environment and Conservation of Natural Resources, Regional Center of Rabat, National Institute of Agricultural \\ Research (INRA),PO Box 6356,Rabat, Morocco.
}

\begin{abstract}
Due to over-exploitation of water resources, the high basin of Guir posed an alarming risk of elimination in terms of quantity and quality. Therefore, this study intends to evaluate the physical and chemical quality of groundwater in the high Basin of Guir and to identify possible sources of pollution in order to map the quality of the Jurassic groundwater. During May 2018, thirty water points, distributed in the high basin of Guir, were sampled and analysed to determine concentrations of sevenchemical elements: $\mathrm{K}^{+}, \mathrm{Na}^{+}, \mathrm{Ca}^{++}, \mathrm{Mg}^{++}, \mathrm{Cl}^{-}, \mathrm{HCO}_{3}^{-}, \mathrm{SO}_{4}^{-}$. In addition, $\mathrm{EC}$ (Electric Conductivity), $\mathrm{pH}, \mathrm{T}^{\circ}$ and the piezometric level (PL) weremeasured.To study and compare, we treated statistically all data by Principal Component Analysis (PCA) and SIG.Analysis of the overall quality of water displayed results that range from good to poor quality. The degradation of water quality in the aquifer of the high basin of Guir could be geological and anthropic.
\end{abstract}

Keywords: High Guir Basin, Groundwater, Geostatistical, Physicochemical analysis, Mineralization, Morocco

\section{Introduction}

In south-eastern Morocco, or more precisely in the high Guir basin, the availability of groundwater of acceptable quality has become a difficult challenge because of the severity of the climate and the risks of pollution (domestic, industrial, agricultural) which weakens and makes these waters vulnerable because of different factors [1]. Therefore, the quantitative and qualitative management of groundwater and surface water resources is currently a necessity $[2,3]$.

The objective of this work is to evaluate the physicochemical quality of groundwater in the Guir Basin region and to identify sources of pollution with a view to establishing a groundwater quality map.A standard sampling procedure was used to collect 30 groundwater samples [4]from the various wells and boreholes distributed over the study area. For the assessment of groundwater qualitystatistical techniques were used $[1,5]$.

\section{Study area}

The study area is located in the south-east of Morocco, geographically between $X=598000, X=706000$ and $\mathrm{Y}=151000, \mathrm{Y}=231000$ (UTM geographical projection system), total area is $4005 \mathrm{~km}^{2}$ (Figure 1).

The high Guir Basin is located in a semi-desert bioclimatic stage. Temperatures have significant seasonal variations with a very hot summer and a very cold winter [1]. The annual rainfall regime is characterized by the existence of two rainy seasons: autumn and spring [1]; with an average annual rainfall reaching $250 \mathrm{~mm}$ in the high Basin and $112 \mathrm{~mm}$ at the downstream of the basin. 


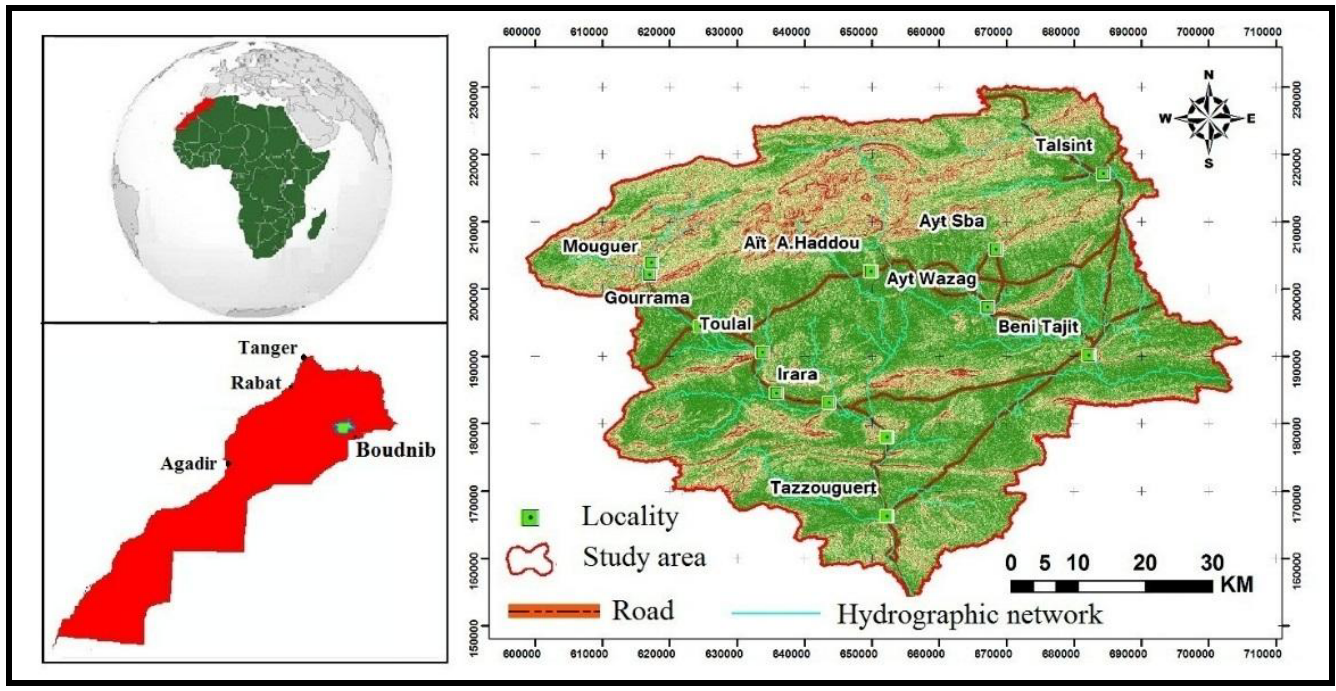

Fig. 1.Geographical situation of the studied area

\subsection{The geological and Hydrogeological framework}

The geological formations in the area are mainly composed of Jurassic sedimentary rocks [6, 7, 8, 9] dominated by marl and limestone. The Triassic is composed of detrital depositsthat lie in angular unconformity on Palaeozoic bedrock [8,9]. The region is characterized by a vast geological structure, including fracture systems at different scales and mechanisms, which play an influential role in increasing the porosity and permeability of the rocks (Figure 2).

The boreholes data provided by AHGZR and the electrical sounding carried out by the Public Laboratory of Essays and Studies (LPEE 1992-1993) enabled us to describe the stratigraphy of the sedimentary basin between the Triassic and the recent Quaternary periods. According to these works, the high Guir basin contains aquifers made up of Jurassic limestones age (Domerian, Alenenian and Dogger) and an alluvial aquifer (alluvial quaternary) $[5,10]$.

The aquifer systems in thehigh Guir watershed are : 1) Plio-Quaternary alluvium aquifers containing essentially, conglomerates, gravels and pebbles, located along the valleys ; 2) Cretaceous Aquifer generally containing limestone with a karst behavior, sand and sandstone ; 3) Lias-Domerian lower aquifer with limestone and dolomite, often fractured and sometimes karstified ; 4) Aalenian-Dogger aquifer with the limestone marl with cracked and karst networks $[5,10]$.

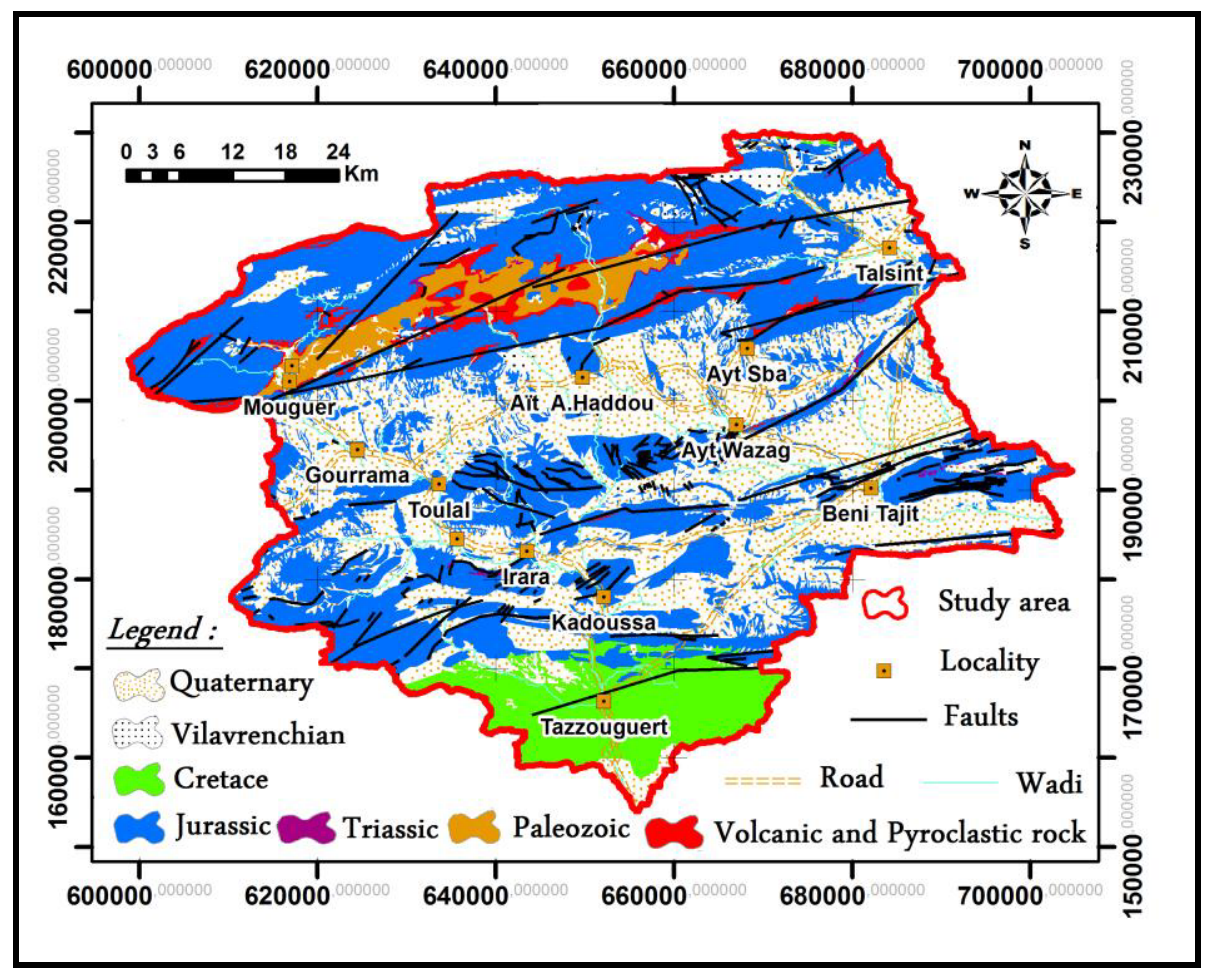

Fig.2.Geological map of the studied area. 


\section{Data and methods}

\subsection{Data}

The hydrochemical data used are essentially the results of the physicochemical analyses of the water samples taken in May 2018 from 30 boreholes in the region (Figure 3). These boreholes were selected in a manner to cover the entire study area. Water samples were analysed at the ONEP-E Laboratory. Temperature $\left(\mathrm{T}^{\circ}\right)$, electrical conductivity (EC) and $\mathrm{pH}$ were measured in the field and water samples were collected for ion determination. The $\mathrm{pH}$ and conductivity were measured using a $\mathrm{pH}$ meter and a digital conductivity meter, respectively, with uncertainties of \pm 0.1 and $\pm 0.1 \mu \mathrm{S} . \mathrm{cm}^{-1}$. The temperature was measured using a thermometer with an uncertainty of $\pm 0.1^{\circ} \mathrm{C}$. During this campaign, the water samples taken were conditioned and stored, protected from dust and light at a temperature of $4^{\circ} \mathrm{C}$. Major and other elements were measured in the laboratory by different techniques. The ions $\mathrm{HCO}_{3}^{-}, \mathrm{Cl}^{-}, \mathrm{NO}_{3}^{-}, \mathrm{SO}_{4}{ }^{2-}, \mathrm{Ca}^{2+}$, $\mathrm{Mg}^{2+}, \mathrm{Na}^{+}$and $\mathrm{K}^{+}$were assayed in the laboratories in a maximum of fifteen days after the samples.

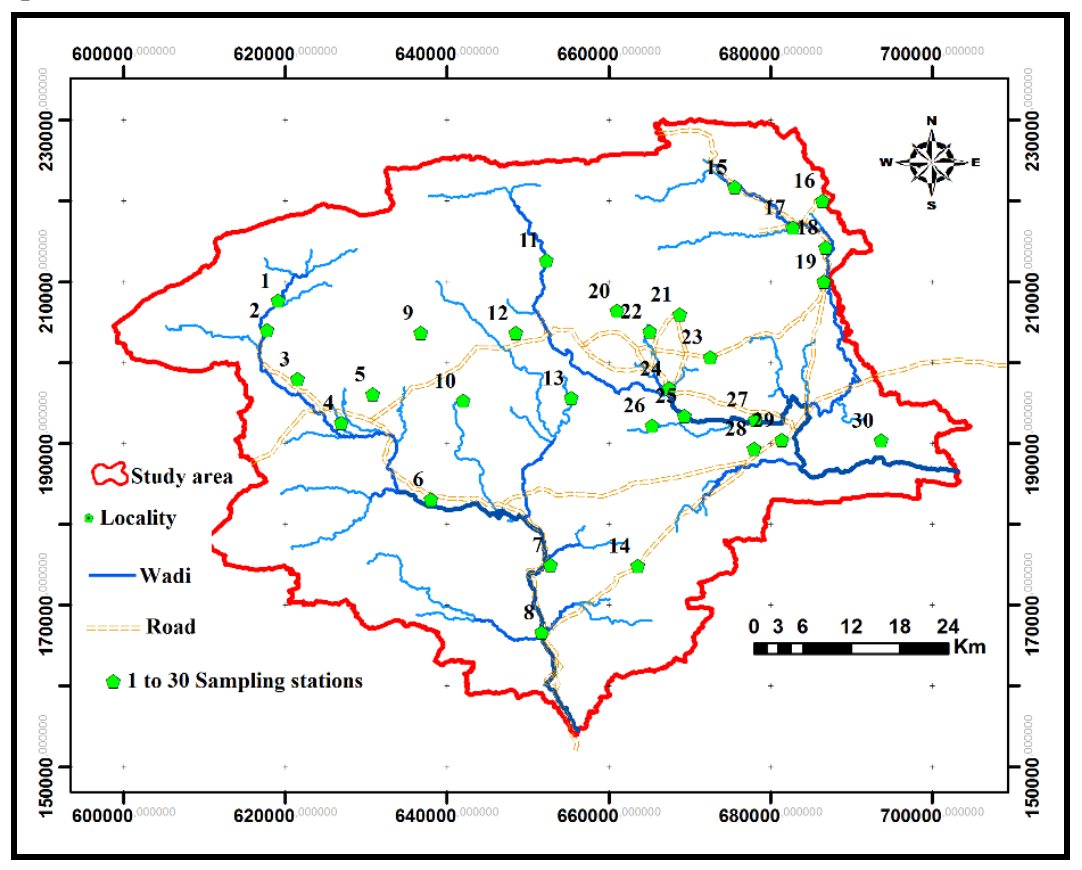

Fig.3.Distribution of the sampling points of Groundwater in thehighBasin of Guir.

\subsection{Dataprocessing method}

The treatment of data collected on groundwater was carried out using hydrochemical and multivariate geostatistical methods.

Principal Components Analysis (PCA) method has been used to highlight the chemical resemblances between the different waters and to understand the different mechanisms underlying the mineralization of groundwater to study the phenomena causing the mineralization of the water. This geostatistical method is widely used to interpret hydrochemical data of hydrosystems[11, 12, 13, 1]. TheStatistical analysis was performed using the STATISTICA 6.0 softwareon 30 descriptors and 14 variables which are: $\mathrm{HCO}_{3}{ }^{-}, \mathrm{Cl}^{-}, \mathrm{NO}_{3}^{-}$, $\mathrm{SO}_{4}{ }^{2-}, \mathrm{Ca}^{2+}, \mathrm{Mg}^{+}, \mathrm{Na}^{+}, \mathrm{K}^{+}, \mathrm{T}^{\circ}, \mathrm{pH}, \mathrm{CE}, \mathrm{PT}, \mathrm{RS}$ and NP.The results of the chemical analyses were compared to values [14] in the context of drinking water, not influenced by anthropogenic activities. The application of all these different methods made it possible to know the mechanism of mineralization of the waters of Jurassic aquifers of the high Guir Basin. We present here the main results obtained in this study.

\section{RESULTS AND DISCUSSIONS}

\subsection{Results of the identification of explanatory variables by the ACP}

Principal Components Analysis (PCA) results are presented in tabular or graphical form to synthesize information and facilitate interpretations. This technique of analysis of an array of data can be used to try to identify similarities between water points relative to the studied variables (physicochemical parameters).

\subsubsection{Choice of Eigenvalues (selectable number of factors)}

The table of eigenvalues (Table 2) shows that the first three factors represent $61.13 \%$ of the variance expressed. These factors combine the maximum of the variance expressed and are enough to accurately translate the information sought.

The factor F1, with a variance of $30.80 \%$, is the most important factor. Then come the factors F2, F3 and F4 with respectively $48.84 \%, 61.13 \%$ and $70 \%$ of the variance expressed. The factors selected are those whose eigenvalues are greater than or equal to 1 . Added to this 
is the criterion according to which the set of factors selected must have a variance greater than or equal to $70 \%$. Given these different conditions, the first three factors can be retained. Indeed, the eigenvalues of these factors vary between $1.60(\mathrm{~F} 3)$ and $4(\mathrm{~F} 1)$. Also, the cumulative variance is estimated at $61.13 \%$. The factorial axes selected for this statistical analysis are representative of the variance of the data set. The factorial designs $\mathrm{F} 1-\mathrm{F} 2$ and F1-F3 thus represent respectively cumulative variances equal to $49 \%$ and $43.08 \%$. In view of these percentages expressed, it can be considered that the mechanisms that control the variation of the electrical conductivity of groundwater are largely contained in the first three factors. As a result, the analysis was carried out on the factorial F1-F2 and F1-F3 which highlight the general trends.

Table 2. The table of eigenvalues.

\begin{tabular}{|c|c|c|c|c|}
\hline Facteurs & Eigenvalue & $\begin{array}{c}\text { \% Total } \\
\text { variance }\end{array}$ & $\begin{array}{c}\text { Cumulative } \\
\text { Eigenvalue }\end{array}$ & Cumulative \% \\
\hline Factor 1 & 4 & 30,80 & 4,00 & 30,80 \\
\hline Factor 2 & 2,35 & 18,04 & 6,35 & 48,84 \\
\hline Factor 3 & 1,60 & 12,28 & 7,95 & 61,13 \\
\hline Factor 4 & 1,12 & 8,62 & 9,07 & 70 \\
\hline
\end{tabular}

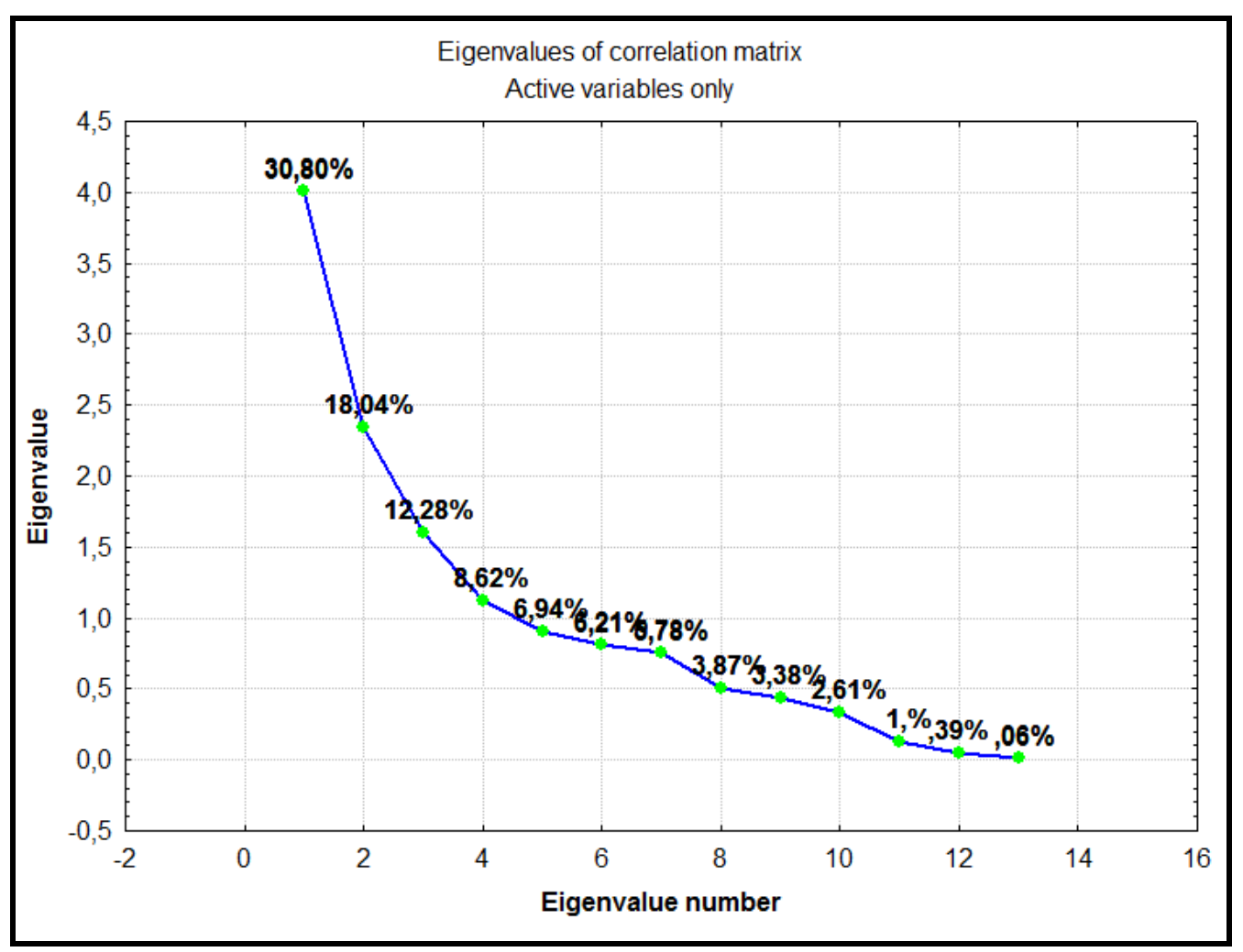

Fig. 9.Eigenvalues of correlation matrix

The correlation matrix which presents the different correlations between the variables necessary for the understanding of the phenomena studied is presented in Table 3.

Indeed, this matrix shows an importantcorrelation between the electrical conductivity and the sum of the cations $(\mathrm{R}=0,87)$ and the sum of the anions $(\mathrm{R}=0.98)$. This reflects a major influence of the sum of the cations and that of the anions (explanatory variables) on the electrical conductivity which is the explained variable. Simple linear regression curves were used to assess the quality of the correlations between electrical conductivity and major ions (Figure 10). In addition, the values of the correlation coefficient between electrical conductivity and parameters such as $\mathrm{pH}$ and temperature remain low (respectively, $\mathrm{R}=0.22$ and $\mathrm{R}=-0.28$ ). These low values of the correlation coefficient show that these parameters do not interfere in the determination of the electrical conductivity of water.

The examination of the correlation matrix between variable also shows an important correlation between $\mathrm{Mg}^{++} * \mathrm{SO}_{4}^{--}(0.898)$ and $\mathrm{Cl}^{-*} \mathrm{Na}^{+}(0.856)$.

These different correlations reflect the influence of each parameter on the mineralization of the waters of the Guir high Basin (Table 3). 


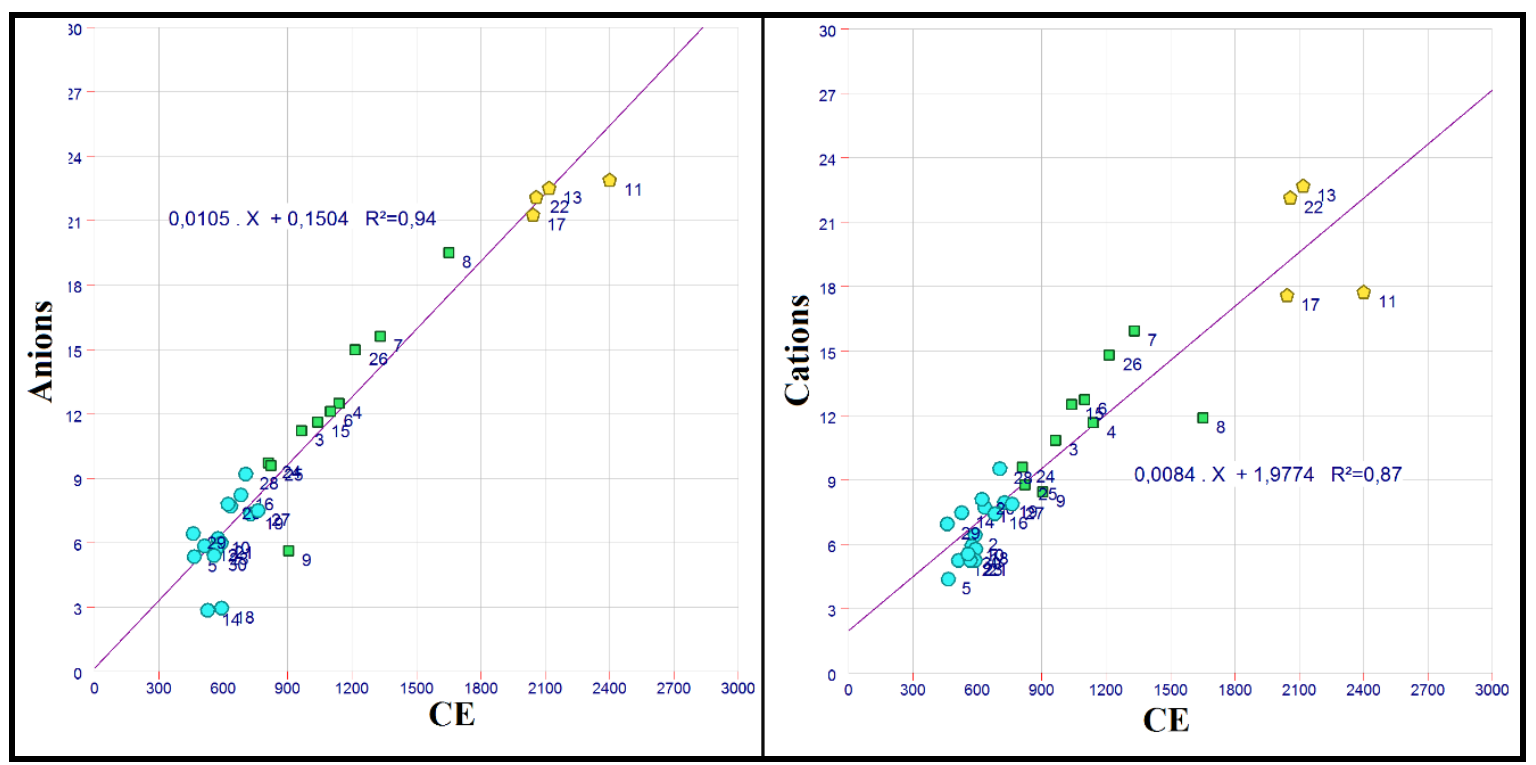

Fig. 10. Correlation between the electrical conductivity and the sum of the cations and the sum of the anions.

Table 3.Correlation matrix of physico-chemical variables.

\begin{tabular}{|c|c|c|c|c|c|c|c|c|c|c|c|c|c|}
\hline & $\mathbf{P T}$ & $\mathbf{N P}$ & $\mathbf{T}^{\circ} \mathbf{C}$ & $\mathbf{R S}$ & $\mathbf{C E}$ & $\mathbf{P H}$ & $\mathbf{K}^{+}$ & $\mathbf{~ a a}^{+}$ & $\mathbf{C a}^{++}$ & $\mathbf{M g}^{++}$ & $\mathbf{C l}^{-}$ & $\mathbf{H C O}_{3}{ }^{-}$ & $\mathbf{S O}_{4}{ }^{--}$ \\
\hline $\mathbf{P T}$ & 1 & & & & & & & & & & & & \\
\hline $\mathbf{N P}$ & 0,145 & 1 & & & & & & & & & & & \\
\hline $\mathbf{T}^{\circ} \mathbf{C}$ & 0,508 & 0,203 & 1 & & & & & & & & & & \\
\hline $\mathbf{R S}$ & $-0,265$ & $-0,137$ & $-0,117$ & 1 & & & & & & & & & \\
\hline $\mathbf{C E}$ & $-0,019$ & $-0,363$ & $-0,281$ & 0,352 & 1 & & & & & & & & \\
\hline $\mathbf{P H}$ & 0,132 & $-0,084$ & 0,201 & 0,034 & 0,221 & 1 & & & & & & & \\
\hline $\mathbf{K}^{+}$ & 0,206 & 0,042 & 0,086 & $-0,189$ & 0,155 & 0,283 & 1 & & & & & & \\
\hline $\mathbf{N a}^{+}$ & 0,323 & $-0,104$ & 0,177 & 0,061 & 0,581 & 0,200 & 0,328 & 1 & & & & & \\
\hline $\mathbf{C a}^{++}$ & 0,068 & $-0,093$ & $-0,067$ & 0,119 & 0,217 & $-0,329$ & $-0,006$ & 0,347 & 1 & & & & \\
\hline $\mathbf{M g}^{++}$ & $-0,087$ & $-0,355$ & $-0,334$ & 0,308 & 0,877 & 0,214 & 0,074 & 0,262 & 0,042 & 1 & & & \\
\hline $\mathbf{C l}^{-}$ & 0,065 & $-0,189$ & 0,055 & 0,160 & 0,575 & 0,024 & 0,193 & 0,856 & 0,465 & 0,297 & 1 & & \\
\hline $\mathbf{H C O}_{3}^{-}$ & 0,213 & 0,165 & 0,114 & $-0,111$ & $-0,085$ & $-0,031$ & 0,317 & 0,110 & 0,098 & $-0,153$ & 0,003 & 1 & \\
\hline $\mathbf{S O}_{4}^{--}$ & $-0,023$ & $-0,335$ & $-0,296$ & 0,363 & 0,960 & 0,236 & 0,120 & 0,434 & 0,158 & 0,898 & 0,377 & $-0,168$ & 1 \\
\hline
\end{tabular}

Table 3 show the contribution of the different variables and principle factors. Results indicate that the F1 factor, defined by $\mathrm{CE}(\mathrm{r}=0.972), \mathrm{SO}_{4}^{--}(\mathrm{r}=0.914), \mathrm{Cl}-(\mathrm{r}=0.678)$

and $\mathrm{Na}+(\mathrm{r}=0.659)$, is the most important factor.

Table 4: Correlation between the variables and the factors.

\begin{tabular}{|c|c|c|c|c|c|c|c|c|c|c|}
\hline Variables & $\mathbf{F 1}$ & $\mathbf{F 2}$ & $\mathbf{F 3}$ & $\mathbf{F 4}$ & $\mathbf{F 5}$ & $\mathbf{F 6}$ & $\mathbf{F 7}$ & $\mathbf{F 8}$ & $\mathbf{F 9}$ & F10 \\
\hline $\mathbf{P T}$ & $-0,031$ & 0,714 & 0,140 & 0,217 & 0,074 & $-0,537$ & $-0,147$ & 0,104 & $-0,020$ & $-0,300$ \\
\hline $\mathbf{N P}$ & $-0,442$ & 0,267 & $-0,025$ & $-0,058$ & $-0,528$ & $-0,190$ & 0,637 & $-0,006$ & 0,086 & 0,039 \\
\hline $\mathbf{T}^{\circ} \mathbf{C}$ & $-0,264$ & 0,641 & 0,146 & 0,532 & $-0,126$ & 0,007 & $-0,183$ & 0,038 & $-0,152$ & 0,375 \\
\hline $\mathbf{R S}$ & 0,400 & $-0,349$ & $-0,110$ & 0,262 & $-0,675$ & 0,200 & $-0,241$ & 0,177 & $-0,134$ & $-0,182$ \\
\hline $\mathbf{C E}$ & 0,972 & $-0,042$ & 0,081 & $-0,048$ & $-0,042$ & $-0,136$ & 0,044 & $-0,070$ & $-0,016$ & 0,047 \\
\hline $\mathbf{P H}$ & 0,235 & 0,219 & 0,760 & 0,146 & $-0,060$ & 0,304 & $-0,035$ & 0,021 & 0,444 & $-0,038$ \\
\hline $\mathbf{K}_{+}$ & 0,190 & 0,539 & 0,295 & $-0,535$ & 0,054 & 0,252 & 0,090 & 0,411 & $-0,236$ & 0,008 \\
\hline $\mathbf{N a}^{+}$ & 0,659 & 0,615 & $-0,173$ & 0,119 & 0,047 & 0,166 & 0,143 & $-0,185$ & $-0,029$ & $-0,137$ \\
\hline $\mathbf{C a}^{++}$ & 0,316 & 0,200 & $-0,765$ & $-0,032$ & 0,024 & $-0,072$ & $-0,097$ & 0,349 & 0,353 & 0,115 \\
\hline $\mathbf{M g}^{++}$ & 0,836 & $-0,257$ & 0,251 & $-0,088$ & $-0,028$ & $-0,284$ & 0,016 & $-0,022$ & $-0,040$ & 0,170 \\
\hline $\mathbf{C l}^{-}$ & 0,678 & 0,408 & $-0,394$ & 0,135 & 0,075 & 0,301 & 0,153 & $-0,190$ & $-0,066$ & $-0,009$ \\
\hline $\mathbf{H C O}_{3}^{-}$ & $-0,120$ & 0,467 & $-0,077$ & $-0,605$ & $-0,354$ & $-0,063$ & $-0,407$ & $-0,301$ & 0,077 & 0,056 \\
\hline $\mathbf{S O}_{\mathbf{4}}^{-}$ & 0,914 & $-0,151$ & 0,181 & $-0,030$ & $-0,063$ & $-0,248$ & 0,049 & 0,051 & 0,003 & 0,074 \\
\hline
\end{tabular}




\subsubsection{Analysis of the distribution of parameters in the plan F1xF2}

Figure 12.A shows the results of PCA in factorial plane F1-F2. The factor F1 is defined by a grouping situated in its positive part and constituted by the electrical conductivity (CE), $\mathrm{K}^{+}, \mathrm{Na}^{+}, \mathrm{Cl}^{-}, \mathrm{PH}, \mathrm{Ca}^{++}, \mathrm{SO}_{4}^{-}$, $\mathrm{RS}$ and $\mathrm{Mg}^{++}$with a variability of $30,80 \%$. Conversely, the factor
2 is marked by a group consisting of the temperature, $\mathrm{HCO}_{3}{ }^{-}{ }^{+}, \mathrm{Na}^{+}, \mathrm{Cl}^{-}, \mathrm{pH}$ and $\mathrm{Ca}^{++}$in its positive part with a variability of $18.04 \%$.

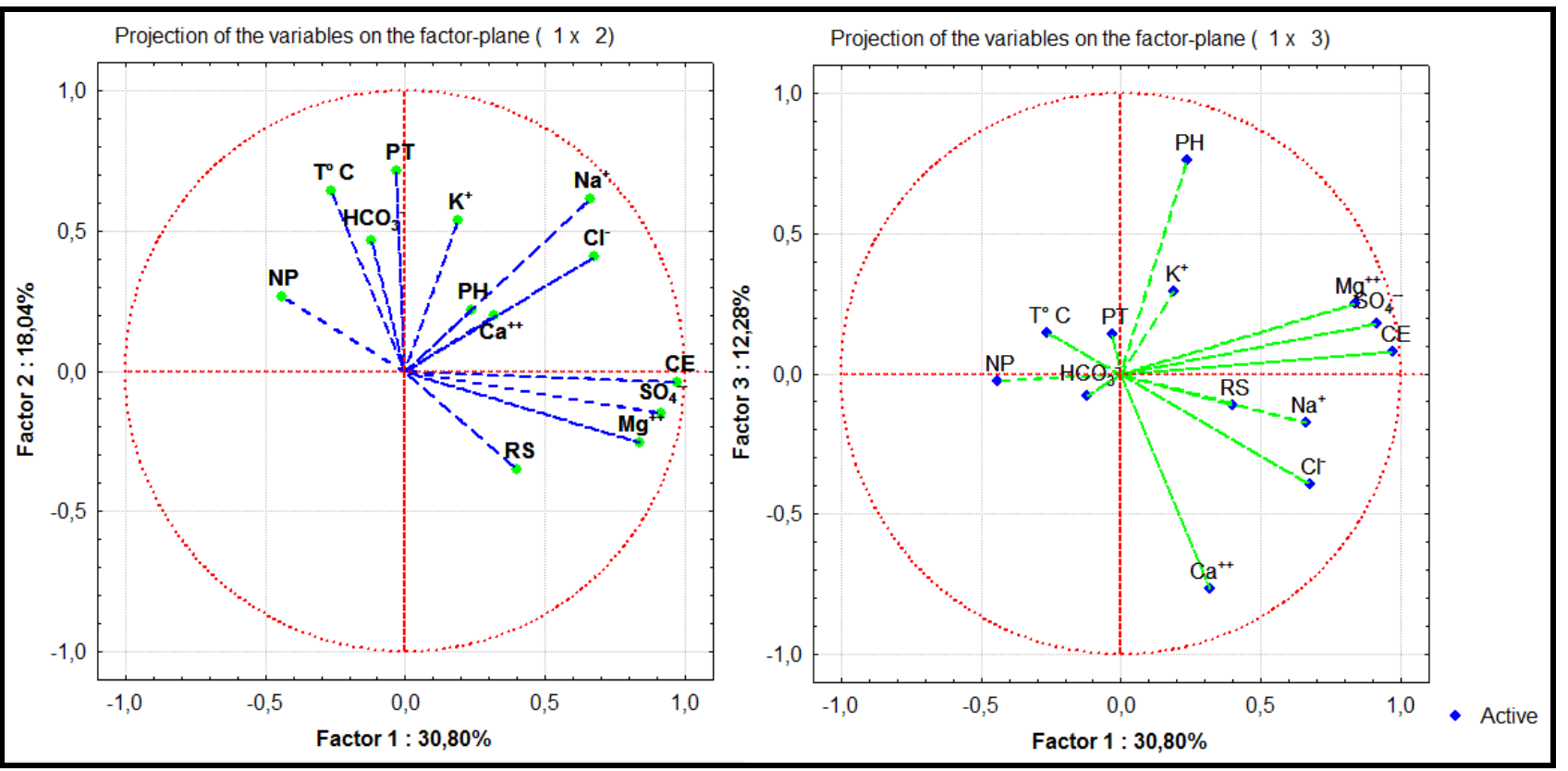

Fig. 12.Projection of the statistical variables in the F1-F2 plane and in the F1-F3 plane

The analysis in the factorial plane F1 -F3 (figure. 12.B) shows the same grouping for the factorial plane F1. The factor F3 is defined by two groupings. The first group, consisting of the temperature, $\mathrm{K}^{+}, \mathrm{Mg}^{+}, \mathrm{SO}_{4}{ }^{-}, \mathrm{CE}$, and $\mathrm{pH}$, is located in its positive part. The second grouping consists of $\mathrm{HCO}_{3}{ }^{-}, \mathrm{RS}, \mathrm{Na}^{+}, \mathrm{Cl}^{-}$, and $\mathrm{Ca}^{++}$, is located in its negative part with a variability of $12.28 \%$.

The results of the PCA indicate that most of the physicochemical parameters studied do not all influence the electrical conductivity, with the exception of $\mathrm{Mg}^{++}$ and $\mathrm{SO}_{4}{ }^{-}$which are very close to electrical conductivity in the factorial plane F1-F2 and also in the factorial plane F1-F3. In addition to $\mathrm{Mg}^{++}$and $\mathrm{SO}_{4}^{-}$the sum of the major cations and the sum of the major anions more influence the electrical conductivity. Indeed, electrical conductivity is an indicator of overall mineralization). It turns out that the electrical conductivity is influenced by the chemical parameters of the water which are summarized in this case in the sum of the major cations and the sum of the major anions. The approximation of the $\mathrm{pH}$ of the electrical conductivity in the factorial plane F1 -F2, shows that the electrical conductivity is influenced by the $\mathrm{pH}$. However, the analysis of the projection of the variables in the factorial plane F1-F3 completely eliminates the $\mathrm{pH}$ of the variables that can influence mainly the electrical conductivity (figure 12.B). This explains the low correlation $(\mathrm{R}=0.28)$ between these two parameters. In addition, the results show no significant relationship between on the one hand, the electrical conductivity and on the other hand, the temperature and $\mathrm{HCO} 3-$.

The typological structure of the plan analysis F1 x F2 (figure 13) allows the identification of three areas (GI, GII and GIII), depending on the nature of pollutants and theirdegree of contamination. 


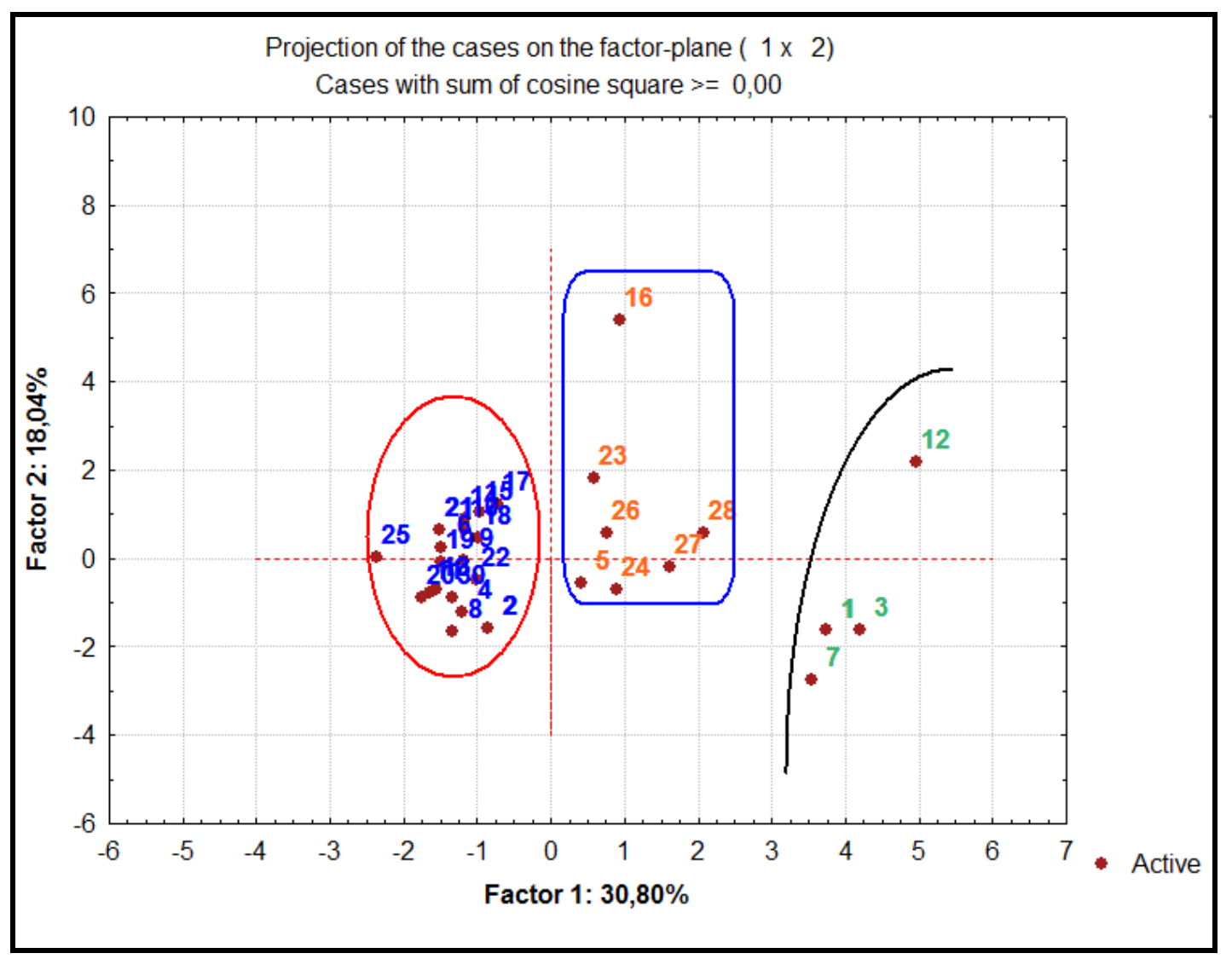

Fig. 13.Representation of water points of the factorial planF1 $\times$ F2

Group I: This group occupies the positive part of the F1 axis. It is represented by water points $1,3,7$ and 12 . The groundwater in this area is characterized by strong mineralization reflected by the high levels of $\mathrm{HCO}_{3}{ }^{-}$, $\mathrm{SO}_{4}{ }^{-}$and $\mathrm{Cl}^{-}$. This heavy load in these chemical elements HCO3- , SO4- and Cl- reflects a very long residence time of groundwater in the aquifer. The state of supersaturation of water in carbonate minerals seems to be mainly due to dissolution of rocks by water, which is a very rapid phenomenon.

Group II: This group occupies the negative parts of F1. It is represented by points $5,16,23,24,26,27$ and 28 . It is characterized by a high chemical element charge $\left(\mathrm{k}^{+}\right.$, $\mathrm{Na}^{+}, \mathrm{Cl}^{-}$and $\left.\mathrm{Ca}^{++}\right)$. The presence of these elements in this groundwater could be related to the geological salts (salts of salts).

Group III: This group occupies the negative parts of F1. It is represented by a cloud of points. It is characterized by a high chemical element charge $\left(\mathrm{HCO}_{3}^{-}, \mathrm{K}^{+}\right.$and $\left.\mathrm{Ca}^{++}\right)$. The presence of these elements in this groundwater could be related to the geological salts.

Moreover, the stations of our study area experiencing heavy mineralization, are in agreement with those found by [5, -15] for the Ziz high basin and of Rheris high basin.

\section{Conclusion}

Several important results were obtained on Jurassic aquifers in the region of the high Guir Basin. In fact, the application of geostatistical tools showed significant connections between electrical conductivity and the various chemical elements, which made it possible to show a strong participation of sulfates, chlorides and sodium in the acquisition of mineralization. The application of principal component analysis has shown that three factors explain almost $50 \%$ of the variance. The factors F1 and F2 are those of the mineralization of groundwater. This method showed the existence of three groups of water depending on the type of mineralization and the nature of the pollutants.

Multivariate analysis methods have shown that the quality of the groundwater in the upper Guir basin is controlled by three major phenomena: anthropogenic activities, rainfall and leaching of soils and hydrolysis of rock minerals. 


\section{References}

1. NouaytiA,Khattach D,Hilali M, Nouayti N. Mapping potential areas for groundwater storage in the High Guir Basin (Morocco):Contribution of remote sensing and geographic information system. Journal of Groundwater Science and Engineering, 2019, 7(4): 309-322.

2. W Ayad, M Kahoul ( 2016). Assessment of physicochemical and bacteriological quality of Well water in the region of ElHarrouch (N.E- Algeria). J. Mater. Environ. Sci. 7 (4) : 1288-1297

3. M. Kahoul, J. Mater. Environ. Sci., 4 (2016) 12881297

4. Blanchette, D. 2006. Caractérisation géochimique des eaux souterraines de la région du bassin versant de la rivière Châteauguay, de Québec, Canada. Mémoire de maîtrise, Québec, Institut National de la Recherche Scientifiue (INRS)-Eau, Terre et Environnement, $71 \mathrm{pp}$

5. Nouayti N, Khattach D, Hilali M, et al. 2016. Assessment of metal contamination in Jurassic water tables of $\mathrm{Ziz}$ high basin (Central High Atlas, Morocco). J Mater Environ Sci, 7:1495-1503

6. El Arabi EH, Diez JB, Bienvenido J, Broutin J, Essamoud R. Première caractérisation palynologique du Trias moyen dans le Haut Atlas, implications pour l'initiation du rifting téthysien au Maroc. C R Geosci; 2006; 338: 641-649

7. Haddoumi H, Charriére A, Mojon PO. Stratigraphie et sédimentologie des "Couches rouges " continentales du Jurassique-Crétacé du Haut Atlas central (Maroc). J Geobios; 2010; 43: 433-451

8. El Kochri A. \&Chorowicz J. 1996. Oblique extension in the Jurassic trough of the central and eastern High Atlas Morocco). Canadian Journal of Earth Science, 33, 8492

9. Teixell A. Arboleya ML, Julivert M, Charroud M. Tectonic shortening and topography of the central High Atlas (Morocco). Tectonics; 2003; 22: 1051

10. Margat J. Plan Blue. L'Eau des Méditerranéens : situation et perspectives, Athènes, PAM; 2004; 158 : 403

11. M. El Morhit, M. Fekhaoui, A. Serghini, S. El Blidi, A. El Abidi, R. Bennaakam, A. Yahyaoui, M. Jbilou (2008). Impact de l'aménagement hydraulique sur la qualité des eaux et des sédiments de l'estuaire du Loukkos (côte atlantique, Maroc). Bulletin de l'Institut Scientifique, Rabat, section Sciences de la Terre, $\mathrm{N}^{\circ} 30$ 39-47.

12. M. Makhoukh, M. Sbaa, A. Berrahou, M. Van. Clooster, (2011). Contribution à l'etude physicochimique des eaux superficielles de l'oued moulouya (maroc oriental), Larhyss Journal, ISSN 1112-3680, nº9, pp. 149-169.
13. M.L Belghiti., A. Chahlaoui, A. Bengoumi, (2013). Caractéristiques physicochimiques des eaux de certains puits utilisés comme source d'eau portable en milieu rural dans la région de Meknès (Maroc), Larhyss Journal, ISSN 1112- 3680, n¹4, Juin, 2136.

14. MCATEE. «Etat de la Qualité des Ressources en Eau au Maroc 2000/2001 .» Ministère chargé del'aménagement du territoire, de l'eau et de l'environnement, 2003: 17.

15. Nouayti A, Khattach D, Hilali M, Nouayti N, et al. 2019. Assessment of groundwater quality using statistical techniques in high Basin of Guir (Eastern High Atlas, Morocco). Materials Today: Proceedings, 13(2019):1084-1091 